La seconde journée, dirigée par M. Théodore Monod, Directeur de l'Institut Français d'Afrique Noire, fut consacrée à l'étude de l'expansion du christianisme en Afrique Noire. La discussion porta sur la possibilité de faire figurer sur une carte les différentes catégories de chrétiens et sur la qualité des sources à consulter. Là encore, les intéressants croquis de M. Mauny serviront à préciser un grand nombre de données.

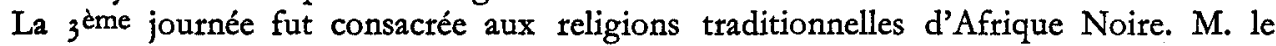
Gouverneur Beyries présenta le problème en général et examina plus spécialement la situation en Sénégal où les religions traditionnelles ont été particulièrement touchées par les monothéismes. M. Rouch a projeté trois films : cérémonie de circoncision dans la boucle $\mathrm{du}$ Niger; danse de possession pour la pluie; enterrement d'un noyé dogon.

Après avoir ainsi envisagé les très grandes lignes du problème, les congressistes tombèrent d'accord sur l'intétêt primordial qu'il y aurait à ce qu'un inventaire soit fait de la situation présente des religions en Afrique Noire et à ce qu'elles soient représentées sur des documents graphiques permettant d'envisager la situation avec clarté.

Il est apparu qu'il importait, tout d'abord, d'établir un document cartographique international indiquant de façon claire les différents groupements humains d'Afrique Noire.

Dans cet esprit, on constata que la carte au I/5.000.000ème en cours d'établissement par le C.H.E.A.M. offre, avec ses croquis d'établissement au millionième, une base acceptable pour porter les indications qui seront recueillies.

D'autre part, les congressistes ont estimé qu'il était souhaitable d'associer à ces recherches les personnes compétentes de toutes nationalités, publiques ou privées, missionnaires ou laịques, et d'obtenir sur place la collaboration d'enquêteurs avisés. En outre ils ont trouvé indispensable d'organiser à Paris un secrétariat permanent qui établirait les canevas d'enquête et les soumettrait aux personnalités compétentes. Ce secrétariat permanent devra également mettre au point une méthode de représentation graphique destinée à donner la situation présente des religions mise en évidence sur une carte renseignée et accompagnée de documents imprimés.

En attendant que soient déterminées les conditions de fonctionnement du Secrétariat Permanent, les correspondances le concernant peuvent être adressées au Conseil Supérieur des Recherches Sociologiques Outre-mer, Section Sociologie des Religions, 20 rue Monsieur, PARIS VII.

\title{
The Bible in African Languages
}

A NEw Bible in the Nupe language has recently been published by the British and Foreign Bible Society. Nupe is a language spoken by some 2 million people living round the Upper Niger; it was reduced to writing for the first time by Bishop Samuel Adjai Crowther, the rescued slave boy who later became the first Bishop of the Niger and was the translator of the Yoruba Bible. In 1908 a Committee was formed and the translation of the Bible was begun by the Rev. A. W. Banfield of the Mennonite Mission, later B.F.B.S. Secretary for West Africa. The New Testament was finished in 1916 and now the Bible has appeared.

Also recently published is the Old Testament in Luo, the work of a committee representing the three missions working the area: the Church Missionary Society, the Africa Inland Mission, and the Seventh Day Adventists. There are about 50,000 Dho Luo Christians. The first Luo scriptures were published in I9I I and the New Testament was completed in 1926.

The Gospel of St. John has been published in Pana, the language of a small group numbering about 18,000 in the province of Ubangi-Chari, French Equatorial Africa. The translator is Miss Estelle Myers. 